\title{
ANALISA PELAYANAN KEFARMASIAN PADA PASIEN RAWAT JALAN DI DEPO FARMASI RSUD IBNU SINA GRESIK BERDASARKAN WAKTU TUNGGU PELAYANAN RESEP
}

\author{
The Analysis of Pharmaceutical Servive For Out patient In Pharmaceutical \\ RSUD IBNU SINA Gresik Based On Respon Time For Prescription Service \\ Nur Anisaus Sholikhah ${ }^{1}$, Pemta Tiadeka ${ }^{2}$, Siti Nur Aisiyah ${ }^{3}$ \\ Universitas Muhammadiyah Gresik \\ RSUD Ibnu Sina Gresik \\ Email : tia.deka1307@umg.ac.id
}

\begin{abstract}
Usually respon time is a waiting time that count from patient giving prescription until they receive medicine. Respon time colud influence patients satisfied if took a long time to get the medicine. Beside that, those fenomena could decrease patient satisication dan they will thought twice to come back to the hospital. Ibnu Sina Hospital try to increase the pharmacy service with observation of respon time in Depo Pharmachy Paviliun. The purpose of those observation is to optimazed pharmacy service by medicine prescription to dispended medicine prescription. This observation is done by retropective methode from January to March 2018. The result of this observation showed that respon time average for medicine prescription is 26 minutes and the average respon time for dispende medicine is 36 minutes. This result is suitable with Phramcacautical Service Standart from Kepmenkes No.129/Menkes/SK/II/2008 about prescription services that said respon time for less medicine prescription is than 30 minutes meanwhile for the other one is less than 60 minutes.
\end{abstract}

Key word: Respon time, concoction Medicine, non concoction Medicine, Standard Pharmacy service

\section{PENDAHULUAN}

Kesehatan merupakan suatu kebutuhan yang paling mendasar bagi setiap manusia. Seiring dengan meningkatnya pengetahuan masyarakat secara tidak langsung menjadikan kesadaran masyarakat terhadap pentingnya kualitas kesehatan juga semakin meningkat. Salah satu tempat pelayanan kesehatan yang menjadi referensi masyarakat adalah Rumah Sakit (Permenkes, 2016). Menurut UndangUndang Nomor 44 Tahun 2009 mengatakan bahwa Rumah Sakit berkewajiban untuk memberi pelayanan kesehatan yang aman, bermutu, anti diskriminasi, dan efektif dengan mengutamakan kepentingan pasien sesuai dengan Standar Pelayanan Rumah Sakit.

Di sisi lain, pelayanan kefarmasian Rumah Sakit merupakan suatu pelayanan langsung dan bertanggung jawab kepada pasien yang berkaitan dengan sediaan Farmasi dengan tujuan meningkatkan kualitas kehidupan pasien.
Dengan adanya pengamatan terhadap waktu tunggu pelayanan obat pasien rawat jalan di Depo Farmasi Paviliun RSUD Ibnu Sina Gresik, maka diharapkan mampu menunjang optimalnya pencapaian Standar Pelayanan Minimum (SPM) di bidang Farmasi. Waktu tunggu merupakan waktu yang dihitung mulai dari resep diterima oleh apoteker hingga obat selesai dibuat dan diserahkan kembali kepada pasien yang bersangkutan. Waktu penerimaan resep pasien dapat dilihat dari hasil input data obat tiap pasien pada program rumah sakit kemudian tercetak dalam faktur penjualan.

Waktu tunggu merupakan salah satu faktor yang mempengaruhi tingkat kepuasan pasien dna pada akhirnya berdampak pada loyalitas pasien terhadap rumah sakit yang bersangkutan. Pelayanan Farmasi merupakan suatu revenue center yang berperan pada pendapatan Rumah Sakit. Hal tersebut dapat ditingkatkan melalui banyaknya pelayanan resep yang mampu terselaikan dengan baik. Disamping itu, penelitian Septini (2011) menyatakan bahwa 
90\% pelayanan kesehatan menggunakan perbekalan Farmasi dan 50\% pemasukan Rumah Sakit berasal dari perbekalan Farmasi.. Berdasarkan uraian diatas maka sangat perlu adanya evaluasi waktu tunggu terutama waktu tunggu pada pelayanan obat jadi dan obat racikan. Saat ini, masih banyak pasien yang memberikan kritik tentang waktu tunggu obat di antaranya dapat dilihat pada hasil laporan watu tunggu pada Depo Farmasi Poli Rawat Jalan Rumah sakit $\mathrm{X}$ dimana waktu tunggu yang didapat rata-rata pada tahun 2017 untuk obat jadi adalah 43.75 menit dan obat racikan 59.6 menit. Di Depo Farmasi Rawat Jalan RS tersebut memiliki nilai waktu tunggu yang belum memenuhi dengan Standar Pelayanan Minimal dan sangat berpengaruh terhadap pelayanan obat terhadap pasien.

Pada tahun 2017 Depo Farmasi Paviliun RSUD Ibnu Sina belum pernah melakukan analisa waktu tunggu sedangkan berdasarkan studi pendahuluan menyatakan bahwa masih banyak pasien Depo Farmasi Paviliun mengeluh tentang pelayanan obat yang lama. Berdasarkan permasalahan tersebut, maka perlu dilakukan kajian lebih lanjut tentang pengamatan waktu tunggu pada pasien rawat jalan non BPJS di Depo Farmasi Paviliun yang juga melayani pelayanan obat untuk pasien rawat inap untuk mengetahui pencapaian standar pelayanan kefarmasian Depo Farmasi Paviliun menurut Kepmenkes No.129/Menkes/SK/II/2008. Indikator ketentuan waktu tunggu dari Standar Pelayanan Minimum Kepmenkes untuk Farmasi adalah kurang dari 30 menit untuk obat jadi dan obat racikan kurang dari 60 menit.

\section{II.TINJAUAN PUSTAKA}

Faaktor-faktor penting yang menunjang dalam mengelola Instalasi Farmasi yaitu staf dan tata letak fasilitas bangunan fisik. Disamping itu faktor penting lainnyayang perlu diperhatikan dalam pelayanan resep yaitu pelayanan yang cepat dan ramah, jaminan tersedianya obat dengan kualitas baik harga kompetitif, serta kerja sama dengan unsur lain di Rumah Sakit misalnya dokter dan perawat. Selanjutnya, hal lain yang berperan adalah kenyamanan ruang tunggu, kemudahan akses untuk memperoleh obat dan ketersediaan obat (Siregar dan Amalia 2004).

Pelaksanaan pelayanan Farmasi terdiri dari 4 pelayanan yaitu:

\section{a. Pelayanan obat Non Resep}

Pelayanan yang diberikan kepada pasien yang ingin melakukan pengobatan sendiri, dapat dikenal dengan swamedikasi. Macam-macam Obat untuk Swamedikasi yaitu obat wajib apotik (OWA), obat bebas terbatas (OBT) dan obat bebas ( OB).

\section{b. Pelayanan Komunikasi, Informasi dan Edukasi ( KIE )}

Setiap petugas Farmasi hendaknya mampu berkomunikasi secara baik dengan tenaga kesehatan lain, perawat, bidan, termasuk kepada dokter memberi informasi tentang obat baru atau obat yang sudah ditarik. Setiap petugas seharusnya aktif dalam tentang keluhan pasien terhadap obat-obatan yang dikonsumsi.

\section{c. Pelayanan Obat Resep}

Pelayanan resep sepenuhnya menjadi tanggung jawab Apoteker Pengelola Apotek. Peraturan menyebutkan bahwa apoteker tidak diizinkan mengganti obat yang tertulis dalam resep dengan obat lain tanpa seizin dokter yang menulis.

\section{d. Pengelolaan Obat}

Kompetensi yang penting adalah dalam bidang obat meliputi kemampuan merancang, membuat, melakukan pengelolaan obat yang efektif dan efisien. Peraturan Menteri Kesehatan RI nomor 72 tahun 2016 tentang Standar Pelayanan Kefarmasian Rumah Sakit menyebutkan bahwa adalah suatu pelayanan langsung dan bertanggung jawab kepada pasien yang berkaitan dengan sediaan Farmasi agar tercapai hasil peningkatan mutu kesehatan pasien.

Standar Pelayanan Minimal menurut 129/Menkes/SK/II/2008 adalah ketentuan tentang jenis dan mutu pelayanan dasar yang merupakan kewajiban daerah yang diperoleh berhak setiap warga secara minimal. Disamping itu, Standar Pelayanan Minimal merupakan spesifikasi teknis tentang acuan pelayanan minimum yang diberikan oleh Badan Layanan Umum kepada masyarakat.

Pada dasarnya waktu tunggu pelayanan resep dibagi menjadi dua yaitu waktu tunggu resep obat jadi dan waktu tunggu resep obat racikan. Menurut Kepmenkes 129/Menkes/SK./II/2008 tentang Standar 
Pelayanan Minimum Rumah Sakit yang menjelaskan bahwa waktu tunggu pelayanan resep obat jadi adalah tenggang waktu mulai pasien menyerahkan resep sampai dengan menerima obat jadi. Selanjutnya waktu tunggu pelayanan resep obat racikan adalah tenggang waktu mulai pasien menyerahkan resep sampai dengan menerima obat racikan.

Di sisi lain, waktu tunggu pelayanan obat juga dapat dikatakan sebagai jarak waktu antara pasien menyerahkan resep kepada Petugas Farmasi sampai dengan pasien menerima obat. Waktu tunggu dapat mempengaruhi kualitas pelayanan dan kepuasan pasien. Guna mengukur pencapaian standar yang telah ditetapkan diperlukan indicator yang mengarah pada ukuran kepatuhan terhadap standar yang telah ditetapkan. Batas Standar Pelayanan Minimal untuk Pelayanan Farmasi mengenai waktu tunggu khusus obat jadi adalah kurang dari 30 menit, sedangkan standar waktu pelayanan untuk resep racikan yaitu kurang dari $60 \%$ (menkes,2008).

Waktu tunggu merupakan salah satu faktor yang dapat mempengaruhi kepuasan pasien. Waktu tunggu yang lama merupakan salah satu komponen yang potensial menyebabkan ketidak puasan pasien. Waktu tunggu (respon time) dapat berpengaruh pada kenyamanan pasien dan utilitas pasien dimasa akan datang. Disamping itu lama waktu tunggu pelayanan resep dapat mencerminkan kinerja dari Tenaga Farmasi dalam melakukan pelayanan kepada pasien. Salah satu strategi dalam mewujudkan pelayanan prima di Depo Farmasi harus dapat mengoptimalkan waktu tunggu yang sedikit untuk pelayanan resep obat jadi maupun obat racikan (Septini, 2011).

Secara keseluruhan Depo Farmasi memiliki tujuan yaitu memberikan obat yang akurat dan tepat waktu serta memberikan KIE yang tepat juga (Megawati,2015). Guna mencapai pelayanan kesehatan yang bermutu, maka rumah sakit diharapkan mampu memenuhi Standar Pelayanan Minimal yang telah ditetapkan oleh pemerintah dalam Keputusan Menteri Kesehatan (Kepmenkes) Republik Indonesia Nomor:129/Menkes/SKII/2008 tentang Standar Pelayanan Minimal Rumah Sakit.

Kecepatan pelayanan resep tergantung pada proses yang dilaksanakan pada saat pelayanan Farmasi. Proses pelayanan Farmasi terdiri dari perencanaan, pengadaan, produksi, penyimpanan sediaan Farmasi, dispensing obat, pengendalian mutu dan distribusi serta penggunaan seluruh perbekalan kesehatan di Rumah Sakit, pelayanan Farmasi klinik umum dan spesialis.

Saat ini, seiring dengan bertambahnya pengetahuan, pelayanan kefarmasian menga;ami perkembangan pelayanan dari obat ke pasien yang kemudian mengacu kepada Pharmaceutical Care. Pada awalnya kegiatan pelayanan kefarmasian hanya terpusat pada pengelolaan obat sebagai komoditi yang bertujuan untuk meningkatkan kualitas hidup dari pasien. Hal ini menyebabkan Apoteker dan Tenaga Teknis Kefarmasian dituntut untuk meningkatkan pengetahuan, ketrampilan dan perilaku agar dapat melaksanakan interaksi langsung dengan pasien secara optimal.

\section{III.METODE PENELITIAN}

\subsection{Alat dan bahan}

Alat yang digunakan pada penelitian ini adalah data entri resep yang ada pada SIMRS (Sistem Informasi Manajemen Rumah Sakit). Bahan yang digunakan pada penelitian adalah resep pasien Rawat Jalan Depo Paviliun RSUD Ibnu Sina Gresik pada bulan Januari 2018 sampai Maret 2018.

\subsection{Cara Kerja}

Penelitian yang dilakukan merupakan penelitian secara retrospektif yang dilakukan dengan cara mengambil data resep-resep di Depo Farmasi RSUD Ibnu Sina Gresik pada bulan sebelumnya yaitu bulan Januari 2018 sampai Maret 2018.

Jumlah sampel yang akan diambil untuk penelitian ini berdasarkan Rumus Slovin (Marfilia G, 2017) yang dijelaskan sebagai berikut :

Keteran

$$
\mathrm{n}=\frac{N}{1+N(d)^{2}}
$$

$\mathrm{N}=$ besar populasi

$\mathrm{n}=$ besar sampel

$\mathrm{d}=$ Tingkat kepercayaan / ketepatan yang diinginkan $(0,05)$

Selanjutnya, nilai waktu tunggu pelayanan resep dihitung menggunakan rumus:

$$
\mathrm{X}=\frac{b}{a}
$$

Keterangan : $\mathrm{b}$ : Waktu tunggu a: Jumlah resep 


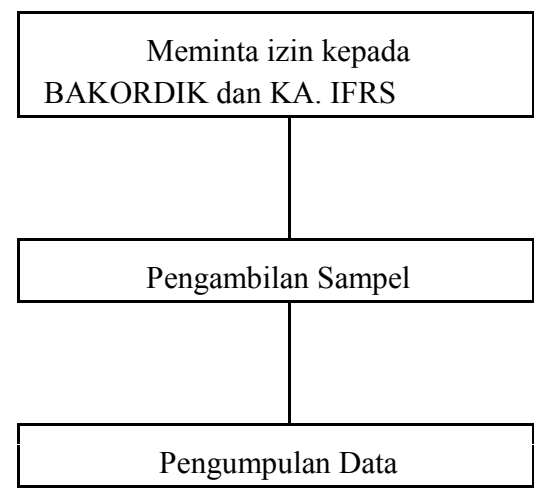

Gambar 3.1 Alur Penelitian

\section{HASIL DAN PEMBAHASAN}

Hasil penelitian terhadap waktu tunggu selama bulan Februari sampai Maret 2019 dapat dilihat pada Tabel 4.1. Perhitungan presentase didasarkan pada perbandingan jumlah lembar resep dengan total waktu tunggu. Terdapat variasi perbedaan waktu tunggu dari bulan januari sampai maret 2019. Waktu tunggu terpendek terletak pada bulan Januari untuk obat jadi sedangkan waktu tunggu terpanjang berada pada bulan Februari dengan kategori obat racikan.

Tabel 4.1 Hasil perhitungan rata-rata waktu tunggu Di Depo Farmasi Paviliun RSUD Ibnu Sina Gresik

\begin{tabular}{|c|c|c|c|c|}
\hline Bulan & $\begin{array}{c}\text { Jenis } \\
\text { resep }\end{array}$ & $\begin{array}{c}\text { Jumlah } \\
\text { sampel } \\
\text { lembar }\end{array}$ & $\begin{array}{c}\text { waktu } \\
\text { tunggu }\end{array}$ & $\begin{array}{c}\text { Rata-rata } \\
\text { Presentase } \\
\text { waktu tunggu } \\
\text { resep } \\
\text { (menit/lembar } \\
\text { Januari }\end{array}$ \\
\cline { 2 - 5 }
\end{tabular}

Dari perhitungan yang ada pada tabel 4.1 didapatkan hasil rata-rata waktu tunggu pada bulan Januari untuk obat jadi adalah 19 menit dan obat racikan 23 menit, pada bulan Februari untuk obat jadi adalah 20 menit dan obat racikan 46 menit, pada bulan Maret untuk obat jadi adalah 18 menit dan obat racikan 37 menit. Hasil dari pengamatan waktu tunggu tersebut kemudian akan dibandingkan dengan standar pelayanan kefarmasian yang tertera kepmenkes 129/Menkes/SK./II/2008. Hasil perbandingan dapat dilihat pada Tabel 4.2

Tabel 4.2 Hasil perbandingan waktu tunggu dengan Kepmenkes

\begin{tabular}{|c|l|l|l|l|}
\hline Bulan & \multicolumn{1}{|c|}{$\begin{array}{c}\text { Jenis } \\
\text { resep }\end{array}$} & $\begin{array}{c}\text { Waktu } \\
\text { tunggu }\end{array}$ & \multicolumn{1}{|c|}{ SPM } & Kategori \\
\hline \multirow{2}{*}{ Januari } & Obat jadi & 19 menit & $\leq 30$ menit & Sesuai \\
\cline { 2 - 5 } & $\begin{array}{l}\text { Obat } \\
\text { racikan }\end{array}$ & 23 menit & $\leq 60$ menit & Sesuai \\
\hline \multirow{2}{*}{ Februari } & Obat jadi & 20 menit & $\leq 30$ menit & Sesuai \\
\cline { 2 - 5 } & $\begin{array}{l}\text { Obat } \\
\text { racikan }\end{array}$ & 46 menit & $\leq 60$ menit & Sesuai \\
\hline \multirow{2}{*}{ Maret } & Obat jadi & 18 menit & $\leq 30$ menit & Sesuai \\
\cline { 2 - 5 } & $\begin{array}{l}\text { Obat } \\
\text { racikan }\end{array}$ & 37 menit & $\leq 60$ menit & Sesuai \\
\hline
\end{tabular}

Keterangan :

SPM : Standar Minimal Pelayanan (sesuai dengan Kepmenkes 129/Menkes/SK./II/2008).

Berdasarkan hasil yang tertera pada tabel 4.2 menunjukkan bahwa waktu tunggu pelayanan resep baik obat jadi dan obat racikan pada bulan Januari sampai Maret 2018 di Depo Farmasi Paviliun sudah memenuhi Standar Pelayanan Minimal Kepmenkes No.129/Menkes/SK/II/2008. Obat racikan membutuhkan waktu pembuatan yang lebih lama diantaranya perhitungan dosis, penyiapan obat yang akan diracik, dan pengemasan ke dalam kertas perkamen apabila resep tersebut harus dibuat sediaan puyer. Selain itu, proses pengemasan dapat dilakukan dalam bentuk sediaan kapsul. Disamping itu, resep dari dokter jantung dan dokter spesialis penyakit dalam memiliki beberapa jenis obat dengan lebih dari tiga macam obat sehingga dapat diaktakan bahwa 
terdapat banyak jenis obat dalam satu resep tersebut.

Pada bulan Maret 2018, dapat diketahui bahwa rata-rata waktu tunggu obat jadi sebesar18 menit dan waktu tunggu obat racikan 37 menit. Hal ini dikarenakan ada bulan tersebut terjadi karena jumlah pasien yang berkunjung serta jenis obat dalam satu resep yang sedikit. Selain itu, untuk obat racikan dalam satu resep hanya 1 jenis serta stok ketersediaan obat yang masih banyak pada depo sehingga tidak memerlukan waktu yang lama untuk mengambil obat tersebut karena apabila stok kosong maka pengambilan obat ke gudang farmasi terlebih dahulu.

Berdasarkan hasil rata-rata waktu tunggu pada bulan Januari sampai dengan Maret 2018 didapatkan hasil bahwa sebagian besar waktu tunggu telah memenuhi peraturan kepmenkes No.129/Menkes/SK/II/2008. Beberapa faktor yang mendukung dari keberhasilan kinerja ini adalah jumlah tenaga kesehatan di Depo Famasi Paviliun yang sebanding dengan jumlah resep yang masuk ke Depo. Disamping itu, pada tahun 2018 ada penambahan tenaga kesehatan yaitu satu orang apoteker dan dua orang TTK (Tenaga Teknis Kefarmasian) sehingga dengan adanya penambahan sumber daya manusia maka penumpukan resep di Depo dapat dikerjakan oleh petugas Farmasi dengan cepat. Selain itu, adanya ketersediaan obat lengkap yang diresepkan ke pasien, peralatan dan fasilitas yang tersedia menunjang kinerja peracikan resep sehingga tidak memerlukan waktu yang lama dalam melakukan pelayanan resep. Fasilitas tersebut diantaranya adalah alat racik puyer hanbon atau pres kertas puyer, alat blender obat dan alat pencetak obat dalam bentuk kapsul. Hal ini membantu dalam mempersingkat wartu peracikan obat karena tidak memerlukan pembungkus obat secara manual (Yulia E, 2016).

\section{PENUTUP}

Berdasarkan hasil pengamatan pada bulan Januari sampai Maret 2018 dapat disimpulkan bahwa waktu tunggu di Depo Farmasi Paviliun cukup bagus dan telah memenuhi standar yang ditetapkan pada Kepmenkes

129/Menkes/SK./II/2008. Rata-rata waktu tunggu resep obat jadi pada bulan Januari untuk obat jadi adalah 19 menit,obat racikan 23 menit. Untuk bulan Februari rata-rata waktu tunggu untuk obat jadi adalah 20 menit dan obat racikan 46 menit selanjutnya bulan Maret memiliki rata-rata waktu tunggu untuk obat jadi adalah 18 menit serta obat racikan 37 menit. Secara keseluruhan, nilai ratarata untuk 3 bulan adalah 19 menit untuk waktu tunggu obat jadi sedangkan waktu tunggu obat racikan memiliki waktu nilai rata-rata 37 menit.

\section{Saran}

Petugas Farmasi sebaiknya meningkatkan kualitas pelayanan di Depo Farmasi RSUD Ibnu Sina Gresik supaya tercapai suatu pelayanan yang bermutu dan memuaskan.

\section{DAFTAR PUSTAKA}

[1] Keputusan Menteri Kesehatan Nomor 129/Menkes/Sk/Ii/2008 Tentang Standar Pelayanan Minimal Rumah Sakit. Jakarta : Menteri Kesehatan.

[2] Marfilia G.Lintang, 2017. "Hubungan Antara Waktu Tunggu Pelayanan Resep Dengan Kepuasan Pasien di Instalasi Farmasi Rumah Sakit Umum Pancaran Kasih GMM.Manado: Universitas Sam Ratulangi

[3] Megawati, 2015. "Penurunan Waktu Tunggu Pelayanan Obat Rawat Jalan Instalasi Farmasi Rumah Sakit Baptis Batu". Jurnal Kedokteran Brawijaya Vol. 28,No.2,.Malang : Universitas Brawijaya Malang.

[4] Menkes RI, 2014. Peraturan Menteri Kesehatan Republik Indonesia Nomor 35 Tahun 2014 Tentang Standar Pelayanan Kefarmasian Di Rumah Sakit. Jakarta :

[5] Menkes RI, 2016. Peraturan Menteri Kesehatan Republik Indonesia No.72 tahun 2016 Tentang Standar Pelayanan Kefarmasian Di Rumah Sakit.

[6] Septini. 2011."Analisis Waktu Tunggu Pelayanan Resep Pasien Askes Rawat Jalan Di Yanmasum Farmasi RSPAD Gatot Soebrototahun 2011". Tesis. Depok: Universitas Indonesia.

[7] Siregar, C.J.P., dan Amalia, L., Farmasi Rumah Sakit Teori dan Penerapan Jakarta: Penerbitan Buku Kedokteran ECG, 2004 
Undang-Undang Republik Indonesia Nomor 44 Tahun 2009 Tentang Rumah Sakit. 2009 ;

[8] Yulia E, 2016, “ Gambaran Sistem Pelayanan Resep Pasien Di Instalasi Farmasi Rawat Jalan Rumah Sakit Karya Bhakti Pratiwi. Bogor : Universitas Islam Negeri Syarif Hidayatullah 